\title{
Development of hybrid fibre reinforced self-compacting concrete as per Nan Su criteria
}

\author{
$A$ Rama Krishna Rao ${ }^{1 *}, N$ Ruben $^{2}$, Srinivasa Reddy $\mathrm{V}^{3}, S V S$ Sankeerth $^{3}$ \\ ${ }^{1}$ Research Scholar of Civil Engineering, V.F.S.T.R, Guntur, Andhra Pradesh, India. \\ ${ }^{2}$ Department of Civil Engineering, V.F.S.T.R, Guntur, Andhra Pradesh, India \\ ${ }^{3}$ Department of Civil Engineering, GRIET, Hyderabad, India.
}

\begin{abstract}
This paper studies the development of hybrid fibre reinforced self-compacting concrete as per Nan Su criteria. Results predicted that various packing factors adopted in the study are 1.12, $1.14,1.16$ and 1.18. Fine aggregate /Total aggregate ratios (s/a ratio) adopted in the study are 0.5 , 0.53 and 0.57 . The optimum combinations of packing factor and s/a ratio are found to be $1.12 \&$ 0.53 and $1.14 \& 0.57$ for M30 grade SCC mixes because these optimum PF and s/a ratio combination gives comparatively better particle packing density in SCC mixes. Better particle packing density enhances the microstructure of SCC mix subsequently more strength and durability can be achieved. As PF increases powder content decreases and aggregate content increases requiring more paste to make the SCC mix workable. Less value PF will have high particle packing density yielding more strength due to improved microstructure of SCC mixes. At PF \& s/a combinations of $1.12 \& 0.53$ and $1.14 \& 0.57$, the workability of SCC mixes is superior because of high paste volume and less aggregate content. Compressive, split-tensile and flexural of M30 grade SCC mixes made with optimum combinations of packing factor and s/a ratios are found to be high.
\end{abstract}

\section{Introduction}

The European Federation of National Associations Representing Concrete (EFNARC) has published specifications and guidelines for the use of SCC that include a wide range of themes, including material selection and mixture design, as well as the importance of testing procedures. Nan Su suggested following important guidelines:

1. The volume ratio of aggregate after lubrication and compaction in SCC is about $59-68 \%$.

2. Since PF value is closely related with compressive strength, by adjusting PF from 1.18 to 1.10 with decrement of 0.02 , the SCC thus obtained could satisfy the compressive strength of range $20-100$ MPa.

3. Reduction in PF value would decrease the content of aggregates and increase the volume of paste, thus, enhancing the passing ability through reinforcement and segregation resistance of SCC.

4. s/a ratio is the volume ratio of fine aggregates to total aggregates, which ranges from $50 \%$ to $57 \%$.
5. It is also suggested that the content of coarse aggregates should be about $50 \%$ of the dry packed unit weight.

6. The solid content of SP is $40 \%$. According to previous engineering experience, the dosage of SP is $1.8 \%$ of the content of binders for meeting the $\mathrm{SCC}$ requirements.

\section{Step-wise procedure of Nan Su mixes design method}

The procedures of the proposed mix design method can be summarized in the following steps:

Step 1: calculation of coarse and fine aggregate contents

Step 2: calculation of cement content

Step 3: calculation of mixing water content required by cement

Step 4: calculation of SCM quantity

Step 5: calculation of mixing water content needed in SCC

Step 6: calculation of SP dosage

\footnotetext{
* Corresponding author: rkraoa@rediffmail.com
} 
Step 7: Adjustment of mixing water content needed in SCC

Step 8: Trial mixes and tests on SCC properties

Step 9: Adjustment of mix proportion

\section{Glass and steel fibre dosage in SCC mixtures at their optimal levels}

Table 1 shows the recommended glass and steel fibre dosages for SCC mixes in the M30 grade.

Table 1. Glass fibre \% dosage for M 30 grade SCC mixes prepared with optimal PF and s/a ratios

\begin{tabular}{|c|c|c|c|}
\hline \multirow{2}{*}{ Type } & $\begin{array}{c}\text { Percentage of Glass fibre by volume of } \\
\text { Concrete }\end{array}$ & $\begin{array}{c}\text { Glass fibre } \\
\mathrm{kg} / \mathrm{m}^{3}\end{array}$ & $\begin{array}{c}\text { Compressive Strength } \\
\mathrm{MPa}\end{array}$ \\
\hline \multirow{3}{*}{ M30GFRSCC } & 0.01 & 0.27 & 38.32 \\
\cline { 2 - 4 } & 0.02 & 0.53 & 39.39 \\
\cline { 2 - 4 } $\begin{array}{c}\mathrm{PF}=1.12 \\
\text { and } \\
\text { s/a }=0.53\end{array}$ & 0.03 & 0.80 & 39.88 \\
\cline { 2 - 4 } & 0.04 & 1.06 & 41.44 \\
\cline { 2 - 4 } & $\mathbf{0 . 0 5}$ & $\mathbf{1 . 3 3}$ & $\mathbf{4 4 . 1 6}$ \\
\hline
\end{tabular}

Table 2. Glass fibre \% dosage for M30 grade SCC mixes prepared with optimal PF and s/a ratios

\begin{tabular}{|c|c|c|c|}
\hline \multirow{2}{*}{ Type } & $\begin{array}{c}\text { Percentage of Glass fibre } \\
\text { by volume of Concrete }\end{array}$ & $\begin{array}{c}\text { Glass fibre } \\
\mathrm{kg} / \mathrm{m}^{3}\end{array}$ & $\begin{array}{c}\text { Compressive Strength } \\
\mathrm{MPa}\end{array}$ \\
\hline \multirow{2}{*}{ M30GFRSCC } & 0.01 & 0.27 & 39.08 \\
\cline { 2 - 4 } & 0.02 & 0.53 & 40.17 \\
\cline { 2 - 4 } $\mathrm{PF}=1.14$ & 0.03 & 0.80 & 40.67 \\
\cline { 2 - 4 } and & 0.04 & 1.06 & 42.27 \\
\cline { 2 - 4 } $\mathrm{s} / \mathrm{a}=0.57$ & $\mathbf{0 . 0 5}$ & $\mathbf{1 . 3 3}$ & $\mathbf{4 5 . 0 5}$ \\
\cline { 2 - 4 } & 0.06 & 1.59 & 40.09 \\
\hline
\end{tabular}

Table 3. Dosage of steel fibre in $\%$ for M 30 grade SCC mixes created using the best PF and s/a ratios

\begin{tabular}{|c|c|c|c|}
\hline \multirow{2}{*}{ Type } & $\begin{array}{c}\text { Percentage of steel fibre } \\
\text { by volume of Concrete }\end{array}$ & $\begin{array}{c}\text { Steel fibre } \\
\mathrm{kg} / \mathrm{m}^{3}\end{array}$ & $\begin{array}{c}\text { Compressive Strength } \\
\mathrm{MPa}\end{array}$ \\
\hline \multirow{2}{*}{ M30SFRSCC } & 0.5 & 39.25 & 38.45 \\
\cline { 2 - 4 } & $\mathbf{1 . 0}$ & $\mathbf{7 8 . 5 0}$ & $\mathbf{4 3 . 4 0}$ \\
\cline { 2 - 4 } $\begin{array}{c}\mathrm{PF}=1.12 \\
\text { and } \\
\mathrm{s} / \mathrm{a}=0.53\end{array}$ & 1.5 & 117.75 & 36.76 \\
\cline { 2 - 4 } & 2.0 & 157.00 & 36.10 \\
\hline
\end{tabular}

Table 4. Dosage of steel fibre in \% for M30 grade SCC mixes created using the best PF and s/a ratios

\begin{tabular}{|c|c|c|c|}
\hline Type & $\begin{array}{c}\text { Percentage of steel fibre } \\
\text { by volume of Concrete }\end{array}$ & $\begin{array}{c}\text { Steel fibre } \\
\mathrm{kg} / \mathrm{m}^{3}\end{array}$ & $\begin{array}{c}\text { Compressive Strength } \\
\mathrm{MPa}\end{array}$ \\
\hline \multirow{2}{*}{ M30SFRSCC } & 0.5 & 39.25 & 39.22 \\
\cline { 2 - 4 } & $\mathbf{1 . 0}$ & $\mathbf{7 8 . 5 0}$ & $\mathbf{4 4 . 2 7}$ \\
\cline { 2 - 4 } $\begin{array}{c}\mathrm{PF}=1.14 \\
\text { and } \\
\mathrm{s} / \mathrm{a}=0.57\end{array}$ & 1.5 & 117.75 & 37.49 \\
\cline { 2 - 4 } & 2.0 & 157.00 & 36.49 \\
\hline
\end{tabular}

\section{Fresh properties of PSCC, SFRSCC, GFRSCC and HFRSCC mixes}

In the table below, fresh properties of M30 grade fibre reinforced self-compacting concretes (SCC) mixes based on optimum combinations of packing factor (PF) and fine aggregate to total aggregate (s/a) ratios were investigated utilising various workability test techniques. 
Table 5. Fresh properties for M30 PSCC, SFRSCC, GFRSCC and HFRSCC mixes

\begin{tabular}{|c|c|c|c|c|c|c|c|c|c|}
\hline & \multirow{2}{*}{$\begin{array}{l}\text { Optimum PFs } \\
\text { and s/a ratios }\end{array}$} & \multirow{2}{*}{$\begin{array}{c}\text { Fly } \\
\text { Ash \% }\end{array}$} & \multirow{2}{*}{$\begin{array}{c}\text { Paste } \\
\text { volume }\end{array}$} & \multicolumn{6}{|c|}{ Fresh properties } \\
\hline & & & & 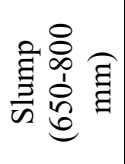 & 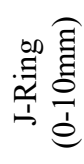 & 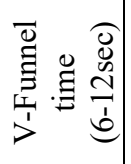 & 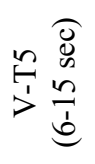 & 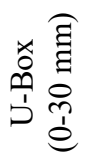 & $\begin{array}{ll}x & 0 \\
0 & 0 \\
m & 1 \\
1 & 0 \\
-1 & 0\end{array}$ \\
\hline M30PSCC & \multirow{4}{*}{$\begin{array}{c}\mathrm{PF}=1.12 \\
\text { and } \\
\mathrm{s} / \mathrm{a}=0.53\end{array}$} & 40.47 & 28.67 & 752 & 5 & 7 & 9 & 21 & 0.93 \\
\hline M30SFRSCC & & 40.47 & 28.67 & 670 & 9 & 10.24 & 12.27 & 29 & 0.82 \\
\hline M30GFRSCC & & 40.47 & 28.67 & 714 & 7 & 9.41 & 10.93 & 26 & 0.90 \\
\hline M30HFRSCC & & 40.47 & 28.67 & 708 & 8 & 9.81 & 11.44 & 28 & 0.87 \\
\hline M30PSCC & \multirow{4}{*}{$\begin{array}{c}\mathrm{PF}=1.14 \\
\text { and } \\
\mathrm{s} / \mathrm{a}=0.57\end{array}$} & 38.33 & 27.59 & 752 & 7 & 8 & 12 & 21 & 0.92 \\
\hline M30SFRSCC & & 38.33 & 27.59 & 682 & 11 & 9.30 & 13.81 & 29 & 0.83 \\
\hline M30GFRSCC & & 38.33 & 27.59 & 742 & 9 & 8.73 & 11.68 & 24 & 0.88 \\
\hline M30HFRSCC & & 38.33 & 27.59 & 727 & 10 & 8.90 & 12.55 & 28 & 0.86 \\
\hline
\end{tabular}

For the best PF and s/a ratio combinations, Table 6 shows the compressive strengths of PSCC, SFRSCC, GFRSCC, and HFRSCC blends.

Table 6. Compressive Strength evaluation of PSCC, SFRSCC, GFRSCC and HFRSCC mixes for optimum PF and s/a ratio combinations of $\mathrm{M} 30$ grade

\begin{tabular}{|c|c|c|c|}
\hline Type & Optimum PFs & $\mathrm{s} / \mathrm{a}$ ratio & $\begin{array}{l}\text { Compressive Strength } \\
\text { (MPa) at } 28 \text { days }\end{array}$ \\
\hline M30PSCC & \multirow{4}{*}{$\mathrm{PF}=1.12$} & 0.53 & 40.35 \\
\hline M30SFRSCC & & 0.53 & 45.35 \\
\hline M30GFRSCC & & 0.53 & 42.15 \\
\hline M30HFRSCC & & 0.53 & 47.07 \\
\hline M30PSCC & \multirow{4}{*}{$\mathrm{PF}=1.14$} & 0.57 & 41.03 \\
\hline M30SFRSCC & & 0.57 & 46.61 \\
\hline M30GFRSCC & & 0.57 & 43.43 \\
\hline M30HFRSCC & & 0.57 & 49.11 \\
\hline
\end{tabular}

$1.12,1.14,1.16$, and 1.18 were some of the packing variables used in the study. The study used fine aggregate/total aggregate ratios ( $\mathrm{s} / \mathrm{a}$ ratios) of 0.50 , 0.53 , and 0.57 . For M30 grade SCC mixtures, the optimal packing factor and s/a ratio combinations were determined to be $1.12 \& 0.53$ and $1.14 \& 0.57$. Because of the high paste concentration in SCC mixes, their workability is higher at packing factor 1.12 , but the strength of the concrete is somewhat lower due to the lack of aggregate component in the mix. We noticed good strength and workability at packing factor 1.14 due to correct mix percentage. We have less paste content than necessary for packing factors 1.16 and 1.18 , which makes the concrete seem harsh and necessitates greater water content and chemical admixtures to make it workable. However, if you add additional water to the concrete, it will bleed, which will impair the compressive strength.

The density of the SCC mixes reduces as PF increases from 1.12 to 1.18 , as does the compressive strength. Because the packing factor affects aggregate content, when PF climbs from 1.12 to 1.18 , powder content and paste volume drop while coarse aggregate content increases. Different kinds of fibres can be used to make Fibre Reinforced Self-Compacting Concrete (SFRSCC, GFRSCC, and HFRSCC mixes). However, maintaining the fresh characteristics of selfcompacting concrete requires the application of the right amount of superplasticizer and viscosity modifying agent. By changing the dose of admixtures, the aspect ratio and volume of steel and glass fibres 
are determined to meet the fresh and hardened characteristics of self-compacting concrete.

\section{Plain and fibre reinforced SCC mixtures were tested for compressive strength.}

At various ages of curing, Table 7 shows compressive strengths of M30 grade plain and reinforced SCC mixes produced with optimal combinations of $\mathrm{PF}$ and s/a ratios.

\section{Split-tensile strength tests on plain and fiber-reinforced SCC mixtures}

At various phases of curing, Table 8 shows splittensile strengths of M30 grade plain and reinforced
SCC mixes produced with optimal combinations of $\mathrm{PF}$ and $\mathrm{s} / \mathrm{a}$ ratios.

\section{Plain and fibre reinforced SCC mixtures were tested for flexural strength.}

Table 9 shows the flexural strengths of plain and reinforced M30 grade SCC mixes produced with the best $\mathrm{PF}$ and s/a ratios at various curing ages.

\section{Plain and fibre reinforced SCC mixtures were evaluated non- destructively.}

Table 10 gives the criteria for evaluating the concrete quality based on Rebound hammer test and ultrasonic pulse velocity (USPV) test.

Table 7. Compressive strengths of M 30 grade PSCC, SFRSCC, GFRSCC, HFRSCC mixes for optimum combinations of $\mathrm{PF}$ and $\mathrm{s} / \mathrm{a}$ ratio

\begin{tabular}{|c|c|c|c|c|}
\hline \multirow{2}{*}{ Mix Type } & \multirow{2}{*}{$\begin{array}{c}\text { Optimum PFs and s/a } \\
\text { ratios }\end{array}$} & \multicolumn{3}{|c|}{ Compressive Strength (MPa) } \\
\hline & & 28 days & 60 days & 90 days \\
\hline M30PSCC & \multirow{4}{*}{$\begin{array}{c}\mathrm{PF}=1.12 \\
\text { and } \\
\mathrm{s} / \mathrm{a}=0.53\end{array}$} & 40.35 & 46.40 & 48.42 \\
\hline M30SFRSCC & & 45.35 & 52.15 & 54.42 \\
\hline M30GFRSCC & & 42.15 & 48.47 & 50.58 \\
\hline M30HFRSCC & & 47.07 & 54.13 & 56.48 \\
\hline M30PSCC & \multirow{4}{*}{$\begin{array}{c}\mathrm{PF}=1.14 \\
\text { and } \\
\mathrm{s} / \mathrm{a}=0.57\end{array}$} & 41.03 & 47.18 & 49.24 \\
\hline M30SFRSCC & & 46.61 & 53.60 & 55.93 \\
\hline M30GFRSCC & & 43.43 & 49.94 & 52.12 \\
\hline M30HFRSCC & & 49.11 & 56.48 & 58.93 \\
\hline
\end{tabular}

Table 8. Split-tensile strengths of M30 grade PSCC, SFRSCC, GFRSCC, HFRSCC mixes for optimum combinations of PF and s/a ratio

\begin{tabular}{|c|c|c|c|c|}
\hline \multirow{2}{*}{ Mix Type } & \multirow{2}{*}{$\begin{array}{c}\text { Optimum PFs and s/a } \\
\text { ratios }\end{array}$} & \multicolumn{3}{|c|}{ Split-Tensile Strength (MPa) } \\
\hline & & 28 days & 60 days & 90 days \\
\hline M30PSCC & \multirow{4}{*}{$\begin{array}{c}\mathrm{PF}=1.12 \\
\text { and } \\
\mathrm{s} / \mathrm{a}=0.53\end{array}$} & 3.83 & 4.41 & 4.60 \\
\hline M30SFRSCC & & 4.31 & 4.95 & 5.17 \\
\hline M30GFRSCC & & 4.00 & 4.60 & 4.81 \\
\hline M30HFRSCC & & 4.47 & 5.14 & 5.37 \\
\hline M30PSCC & \multirow{4}{*}{$\begin{array}{c}\mathrm{PF}=1.14 \\
\text { and } \\
\mathrm{s} / \mathrm{a}=0.57\end{array}$} & 3.90 & 4.48 & 4.68 \\
\hline M30SFRSCC & & 4.43 & 5.09 & 5.31 \\
\hline M30GFRSCC & & 4.13 & 4.74 & 4.95 \\
\hline M30HFRSCC & & 4.67 & 5.37 & 5.60 \\
\hline
\end{tabular}

Table 9. Flexural strengths of M30 grade PSCC, SFRSCC, GFRSCC, HFRSCC mixes for optimum combinations of PF and

\begin{tabular}{|c|c|c|c|c|}
\hline \multirow{2}{*}{ Mix Type } & \multirow{2}{*}{$\begin{array}{c}\text { Optimum } \mathrm{PFs} \text { and } \mathrm{s} / \mathrm{a} \\
\text { ratios }\end{array}$} & \multicolumn{3}{|c|}{ Flexural Strength (MPa) } \\
\hline & & 28 days & 60 days & 90 days \\
\hline M30PSCC & \multirow{4}{*}{$\begin{array}{c}\mathrm{PF}=1.12 \\
\text { and } \\
\mathrm{s} / \mathrm{a}=0.53\end{array}$} & 3.44 & 3.76 & 3.89 \\
\hline M30SFRSCC & & 4.99 & 5.74 & 5.99 \\
\hline M30GFRSCC & & 4.64 & 5.33 & 5.56 \\
\hline M30HFRSCC & & 5.18 & 5.95 & 6.21 \\
\hline M30PSCC & $\mathrm{PF}=1.14$ & 3.51 & 3.78 & 3.99 \\
\hline
\end{tabular}




\begin{tabular}{|c|c|c|c|c|}
\hline M30SFRSCC & \multirow{4}{*}{$\begin{array}{c}\text { and } \\
\text { s } / \mathrm{a}=0.57\end{array}$} & 5.13 & 5.90 & 6.15 \\
\cline { 1 - 3 } \cline { 4 - 5 } M30GFRSCC & & 4.78 & 5.49 & 5.73 \\
\cline { 1 - 3 } M30HFRSCC & 5.40 & 6.21 & 6.48 \\
\hline
\end{tabular}

Table 10. Non-destructive evaluation results of M30 grade PSCC, SFRSCC, GFRSCC, HFRSCC mixes for optimum combinations of $\mathrm{PF}$ and $\mathrm{s} / \mathrm{a}$ ratios

\begin{tabular}{|c|c|c|c|c|c|c|c|}
\hline \multirow[t]{2}{*}{ Mix Type } & \multirow{2}{*}{$\begin{array}{c}\text { Optimum PFs and } \\
\text { s/a ratios }\end{array}$} & \multicolumn{2}{|c|}{$\begin{array}{c}\text { Ultrasonic pulse } \\
\text { velocity } \\
(\mathrm{km} / \mathrm{sec}) \\
\end{array}$} & \multirow{2}{*}{$\begin{array}{l}\text { Concrete } \\
\text { Quality } \\
\text { at } 90 \text { days }\end{array}$} & \multicolumn{2}{|c|}{$\begin{array}{l}\text { Rebound } \\
\text { Number }\end{array}$} & \multirow{2}{*}{$\begin{array}{l}\text { Concrete } \\
\text { Quality } \\
\text { at } 90 \text { days }\end{array}$} \\
\hline & & 28 days & 90 days & & $\begin{array}{c}28 \\
\text { days }\end{array}$ & $\begin{array}{c}90 \\
\text { days }\end{array}$ & \\
\hline M30PSCC & \multirow{4}{*}{$\begin{array}{l}\mathrm{PF}=1.12 \\
\text { and } \\
\mathrm{s} / \mathrm{a}=0.53\end{array}$} & 4.104 & 4.154 & Good & 34 & 35 & Good Layer \\
\hline M30SFRSCC & & 4.150 & 4.130 & Good & 34 & 38 & Good Layer \\
\hline M30GFRSCC & & 4.143 & 4.142 & Good & 38 & 39 & Good Layer \\
\hline M30HFRSCC & & 4.581 & 4.582 & Excellent & 43 & 47 & $\begin{array}{c}\text { Very Good Hard } \\
\text { Layer }\end{array}$ \\
\hline M30PSCC & \multirow{4}{*}{$\begin{array}{c}\mathrm{PF}=1.14 \\
\text { and } \\
\mathrm{s} / \mathrm{a}=0.57\end{array}$} & 4.150 & 4.148 & Good & 33 & 34 & Good Layer \\
\hline M30SFRSCC & & 4.174 & 4.184 & Good & 33 & 35 & Good Layer \\
\hline M30GFRSCC & & 4.184 & 4.178 & Good & 32 & 36 & Good Layer \\
\hline M30HFRSCC & & 4.572 & 4.587 & Excellent & 45 & 47 & $\begin{array}{c}\text { Very Good Hard } \\
\text { Layer }\end{array}$ \\
\hline
\end{tabular}

\section{Conclusions}

Based on the results reported in this research work and key findings during the experimental investigations, the following conclusions are drawn:

1. $1.12,1.14,1.16$, and 1.18 were some of the packing variables used in the study. The study used fine aggregate/total aggregate ratios ( $\mathrm{s} / \mathrm{a}$ ratios) of $0.5,0.53$, and 0.57 . The optimal packing factor and s/a ratio combinations for M30 grade SCC mixes were determined to be $1.12 \& 0.53$ and $1.14 \& 0.57$ because these optimum PF and s/a ratio combinations offer substantially greater particle packing density in SCC mixes. Better particle packing density enhances the microstructure of SCC mix subsequently more strength and durability can be achieved.

2. The PF \& s/a combinations $1.12 \& 0.53$ and 1.14 $\& 0.57$ were found to be the most effective, resulting in the highest compressive strengths, which can be related to the high particle packing densities achieved in SCC mixtures. These optimum combinations of packing factors and $\mathrm{s} / \mathrm{a}$ ratio is further used in the development of the fibre reinforced SCC mixes of grade M30.

3. As PF increases powder content decreases and aggregate content increases requiring more paste to make the SCC mix workable. Less value PF will have high particle packing density yielding more strength due to improved microstructure of SCC mixes.
4. Because of the large paste volume and low aggregate concentration, the workability of SCC mixes is higher for PF \& s/a combinations of $1.12 \& 0.53$ and $1.14 \& 0.57$.

5. SCC ability to flow is reduced for packing factors 1.16 and 1.18 with s/a ratios of $0.50,0.53$, and 0.57 , owing to a lack of paste content, which causes the concrete to seem harsh and necessitates the use of more water and chemical admixtures to make it workable. Due to addition of more water concrete tends to bleed and may affect the compressive strength.

6. A higher value of packing factor $(\mathrm{PF})$ indicates the larger aggregate content with less availability of powder content and will have less flow ability. So higher the PF, workability is reduced which can be enhanced with the usage of high fly ash content subjected to realization of desired strength.

7. M30 grade SCC mixes produced with optimum combinations of packing factor and s/a ratios have high compressive, split-tensile, and flexural properties.

8. Steel, glass, and hybrid (steel + glass) fibres are utilised to generate M40 and M80 grade fibre reinforced SCC mixtures (FRSCC) with optimal packing factors and $\mathrm{s} / \mathrm{a}$ ratios.

9. Experimental research revealed that 0.05 percent glass fibre by volume of concrete and 1.0 percent steel fibre by volume of concrete are the best doses of glass and steel fibres to utilise in M30 SCC mixtures. 0.05 percent glass fibre and 1.0 percent steel fibre by volume of concrete are utilised in hybrid fibre reinforced SCC mixtures. 
10. Addition of fibre reduces workability in SCC mixes. Workability is reduced drastically in SFRSCC when compared to GFRSCC. In HFRSCC mixes, due to addition of steel and glass fibres workability is affected which can be improved using fly ash and super plasticizers.

11. The strengths of the M30 grade PSCC mixes are found to be increased by the addition of fibres. The percentage increase of strength is more significant in M30 grade PSCC mixes made with $\mathrm{PF}=1.14$ and $\mathrm{s} / \mathrm{a}=0.57$

12. The increase of compressive strength of SFRSCC ( steel fibre reinforced self-compacting concrete) and GFRSCC ( glass fibre reinforced self-compacting concrete)) for M30 grade concrete at 28 days in comparison with PSCC (plain self-compacting concrete) was found to be $10-12 \%$.

13. Because steel has a greater modulus of elasticity than glass fibres, the compressive strength of SFRSCC mixes prepared with the best combinations of $\mathrm{PF}$ and $\mathrm{s} / \mathrm{a}$ ratios was found to be higher than that of GFRSCC mixes.

14. The compressive strengths of HFRSCC were found to be significantly increased due to the combined action of glass and steel fibres, with a 16 percent improvement in compressive strength for M30 grade above PSCC produced with optimal combinations of $\mathrm{PF}$ and s/a ratios, respectively.

15. When compared to equivalent HFRSCC and GFRSCC mixes, the inclusion of fibres enhanced split tensile strength, which was found to be highest in M30 SFRSCC mixes.

16. Fibre addition increased flexural strength, which was found to be highest in M30 grade HFRSCC mixtures. As a result, it has been determined that the hybridization of glass and steel fibres is beneficial in enhancing the strength properties of FRSCC. Under flexural loading, GFRSCC blends outperformed SFRSCC mixtures.

17. Non-destructive testing of M30 grade PSCC, SFRSCC, GFRSCC, and HFRSCC mixes made with the best $\mathrm{PF}$ and s/a ratios revealed improved rebound numbers and ultrasonic pulse velocity values for HFRSCC mixes, indicating that HFRSCC mixes have better concrete quality than SFRSCC and GFRSCC mixes due to fibre hybridization enhancing the confining effect partly due to the presence of hi-tech fibres.

\section{References}

1. T.Srinivas and M. Abinay Raj, Int. J. of Eng.and Adv. Tech. (IJEAT), ISSN: 2249 - 8958, Volume-8 Issue-6 (2019)

2. T.srinivas and P. Manoj Anand, Int. J. of Innov. Tech. and Explor. Eng.g (IJITEE), ISSN: 22783075, Volume-8 Issue-12 (2019)
3. T.Srinivas and G. Sukesh Reddy, Int. J. of Eng.and Adv. Tech. (IJEAT), ISSN: 2249-8958, Volume-9 Issue-1 (2019)

4. T.Srinivas and R. N. Koushik, Int. J. of Innov. Tech. and Explor. Eng.g (IJITEE), ISSN: 22783075, Volume-8 Issue-12 (2019), PP 112-117.

5. M. Kavitha, P. B. Bobba and D. Prasad, 2016 IEEE 6th International Conference on Power Systems (ICPS), 2016, pp. 1-6

6. K. Sai Gopi, Dr. T. Srinivas and S. P. Raju V, E3S Web of Conferences ICMED 184, 01084GRIET, 28-29 February, https://doi.org/10.1051/e3sconf/2020184011084 (2020)

7. Jagannadha Kumar, M.V., Jagannadha Rao, K., Dean Kumar, B., Srinivasa Reddy, V., Int. J. of Civil Eng. and Tech., 9(7), pp. 1133-1141 (2018)

8. Ganta, J.K., Seshagiri Rao, M.V., Mousavi, S.S., Srinivasa Reddy, V., Bhojaraju, C., Structures 28, pp. 956-972 (2020)

9. Naidu, K.S.S.T., Rao, M.V.S., Reddy, V.S., Int. J. of Innov. Tech. and Explor. Eng.g (IJITEE), 8(9 Special Issue 2), pp. 641-642 (2019)

10. S. Seshadri, M. Kavitha and P. B. Bobba, 2018 International Conference on Power, Instrumentation, Control and Computing (PICC), 2018, pp. 1-6

11. Chandana Priya, C., Seshagiri Rao, M.V., Srinivasa Reddy, V., Int. J. of Civil Eng. and Tech., 9(11), pp. 2218-2225 (2018)

12. Satya Sai Trimurty Naidu, K., Seshagiri Rao, M.V., Srinivasa Reddy, V., Int. J. of Civil Eng. and Tech., 9(11), pp. 2383-2393 (2018)

13. Supriya, Y., Srinivasa Reddy, V., Seshagiri Rao, M.V., Shrihari, S., Int. J. of Rec. Tech. and Engi., 8(3), pp. 5381-5385 (2019)

14. Kotkunde, N., Krishna, G., Shenoy, S.K., Gupta, A.K., Singh, S.K. International Journal of Material Forming, 10 (2), pp. 255-266 (2017)

15. Govardhan, D., Kumar, A.C.S., Murti, K.G.K., Madhusudhan Reddy, G. Materials and Design, 36, pp. 206-214. (2012)

16. Kumar, P., Singhal, A., Mehta, S., Mittal, A. Journal of Real-Time Image Processing, 11 (1), pp. 93-109. (2016)

17. R. Kumar, A. Sahoo, K. Satyanarayana, and G. Rao, International Journal of Industrial Engineering Computations, 4(3), 427 (2013)

18. Raghunadha Reddy, T., Vishnu Vardhan, B., Vijayapal Reddy, P. International Journal of Applied Engineering Research, 11 (5), pp. 30923102 (2016)

19. Karthik Rao, R., Bobba, P.B., Suresh Kumar, T., Kosaraju, S. Materials Today: Proceedings, 26, pp. 3085-3089, 2019

20. Hussaini, S.M., Krishna, G., Gupta, A.K., Singh, S.K. Journal of Manufacturing Processes, 18, pp. 151-158 (2015) 